\title{
Enhanced Oxidative Stress Markers and Antioxidant Imbalance in HIV Infection and AIDS Patients
}

\author{
P. Pasupathi ${ }^{1}$, T. Ramachandran ${ }^{2}$, P. J. Sindhu ${ }^{2}$, G. Saravanan ${ }^{3}$, and G. Bakthavathsalam ${ }^{2}$ \\ ${ }^{1}$ Institute of Laboratory Medicine, K.G. Hospital and Post Graduate Medical Institute, Coimbatore- \\ 641 018, Tamil Nadu, India \\ ${ }^{2}$ Department of General Medicine, K.G. Hospital and Post Graduate Medical Institute, Coimbatore- \\ 641 018, Tamil Nadu, India \\ ${ }^{3}$ Department of Biochemistry \& Biotechnology, Faculty of Science, Annamalai University, \\ Annamalainagar-608002, Tamil Nadu, India
}

Received 21 January 2009, accepted in revised form 13 April 2009

\begin{abstract}
The aim of this study was to investigate lipid peroxidation as evidenced by thiobarbutric acid reactive substances (TBARS), ceruloplasmin (Ce), $\mathrm{CD}^{4+}$ cells counts and antioxidant, and micronutrients status in HIV infection and AIDS patients. The level of plasma and erythrocyte TBARS, plasma ceruloplasmin was markedly increased in the AIDS patients when compared to HIV infection and healthy control subjects. We observed a significant reduction in $\mathrm{CD}^{4+}$ cell count in HIV/AIDS patients when compared to control subjects. The activities of erythrocyte antioxidants superoxide dismutase (SOD), catalase (CAT), glutathione peroxidase (GPx), glutathione reductase (GR), glutathione $S$-transferase (GST), and reduced glutathione (GSH), were significantly decreased in AIDS patients when compared with HIV infection and healthy subjects. Significantly low levels of plasma GSH, vitamin $\mathrm{A}$ ( $\beta$-carotene), vitamin $\mathrm{C}$, vitamin $\mathrm{E}$, serum uric acid, albumin, selenium and zinc were also observed in AIDS patients when compared with HIV positive patients and control subjects. The study highlights the occurrence of lipid peroxidation and possible breakdown of antioxidant status in HIV/AIDS patients, which may subsequently increase the possibility of poor immunity. The antioxidant status was progressively depleted in HIV infected persons as the disease progressed from a symptomatic state to AIDS.
\end{abstract}

Keywords: Oxidative stress; HIV; AIDS; $\mathrm{CD}^{+}$cell count; Antioxidant status.

C) 2009 JSR Publications. ISSN: 2070-0237 (Print); 2070-0245 (Online). All rights reserved.

DOI: 10.3329 /jsr.v1i2.2295

\section{Introduction}

The acquired immunodeficiency syndrome (AIDS) is a fatal illness caused by a retrovirus known as the human immunodeficiency virus that breaks down the body's immune system that infects $\mathrm{CD}^{4+}$ cells initially and progressively leads to AIDS [1]. There are 2.47

${ }^{1}$ Corresponding author: drppasupathi@gmail.com 
million persons in India living with HIV, equivalent to approximately $0.36 \%$ of the adult population. The revised national estimate reflects the availability of improved data rather than a substantial decrease in actual HIV prevalence in India.

Human immunodeficiency virus (HIV) infection is a worldwide problem and HIV/AIDS patients suffer from several opportunistic infections that occur because of poor immune system function. The hallmark of HIV infection is cellular CD4 immunodeficiency. Different agents appear may trigger apoptosis in $\mathrm{CD}^{+} \mathrm{T}$ cell, including viral protein (i.e. gp 120, Tat), inappropriate secretion of inflammatory cytokines by activated macrophages (i.e. tumor necrosis factor alpha (TNF- $\alpha$ ) and toxins produced by opportunistic microorganism. Since oxidative stress can also induce apoptosis, it can be hypothesized that such a mechanism could participate in $\mathrm{CD}^{+} \mathrm{T}$ cell apoptosis observed in AIDS. Oxidative stress results from the imbalance between reactive oxygen species (ROS) production and inactivation [2]. Under most circumstances, oxidative stress is deleterious to normal cell functions. An emerging view, however, is that, within certain limits, cellular redox status is a normal physiological variable that may elicit cellular response such as transcriptional activation, proliferation or apoptosis. Exposure to oxidants challenges cellular systems and their responses may create conditions that are favorable for the replication of viruses such as HIV.

In HIV-infected patients increased oxidative stress has been implicated in increased HIV transcription through the activation of nuclear factor $\kappa \mathrm{B}(\mathrm{NF}-\kappa \mathrm{B})$. NF- $\kappa \mathrm{B}$ is bound to factor $\mathrm{I} \kappa \mathrm{B}$ in the cytoplasm in its active form, but various factors, such as TNF- $\alpha$ and ROS can cause the release of NF- $\kappa B$ from factor I $\mathrm{BB}$, and NF- $\kappa \mathrm{B}$ translocates to the nucleus and binds to DNA. Glutathione (GSH) is a major intracellular thiol, which acts as a free radical scavenger and is thought to inhibit activation of NF- $\kappa \mathrm{B}$ [3]. NF- $\kappa \mathrm{B}$ is involved in the transcription of HIV-1. Thus, ROS may potentially be involved in the pathogenesis of HIV infection through direct effects of cells and through interactions with NF- $\kappa B$ and activation of HIV replication [4]. The proportion of lymphocytes expressing Fas was shown to be elevated in HIV-infected individuals. Generally these studies demonstrated that the proportion of Fas-expressing cells increases with diseases progression, the increased Fas expression was found by some investigators to be in $\mathrm{CD} 4^{+}$lymphocytes and by others in both $\mathrm{CD} 4^{+}$and $\mathrm{CD} 8^{+} \mathrm{T}$ cells [5].

This malnutrition is accompanied by weight loss which progresses in spurts and which may lead to a genuine cachexia. These patients are thus at high risk of oxidizing stress resulting from antioxidant deficiencies [6]. Oxidizing stress is a pathologic phenomenon resulting from an imbalance between the systems producing active oxygen species and those defending the organism. These defense systems function synergistically to prevent or destroy active oxygen species. Some micronutrients play essential roles in maintaining normal immune function and may protects immune effector cells from oxidative stress [7]. The present study was undertaken to examine the changes in lipid peroxidation, $\mathrm{CD}^{+}$ $\mathrm{T}$ cell counts, antioxidant profile and micronutrients in HIV infection, AIDS patients and HIV-negative controls. 


\section{Materials and Methods}

\subsection{Study population}

The population consisted of 150 subjects divided into three groups was selected. HIV infected patients 50 cases $(n=50)$, AIDS patients 50 cases $(n=50)$ and an equal numbers of age- and sex-matched control subjects $(n=50)$ were investigated. The prospective study was carried out at the K.G.Hospital and Post Graduate Medical Institute, Coimbatore, Tamil Nadu, India from January 2006 to January 2008. For diagnosis and confirmation of HIV infection, we followed the National AIDS Control Organization (NACO) recommendations for HIV testing NACO [8]. All the patients were subjected to detailed history taking and clinical examination. Informed consent of the patients was taken before testing. Individuals were classified according to the Centers for Disease Control and Prevention Criteria (CDC) classification system that emphasizes the importance of CD4 ${ }^{+}$ $\mathrm{T}$ lymphocyte testing in clinical management of HIV-infected persons. The system is based on three ranges of CD4 counts (1) $\geq 500 \mathrm{~mm}^{-3}$; (2) $200-499 \mathrm{~mm}^{-3}$; and (3) $<200 \mathrm{~mm}^{-3}$ [9].

\subsection{Biochemical investigation}

Red blood cell count, total white blood cell count, platelet count, total hemoglobin, hematocrit and ESR were determined using fully automated hematology analyzer (PentraXL 80, Horiba ABX, USA). Uric acid and albumin were determined by using fully automated clinical chemistry analyzer (Hitachi 912, Boehringer Mannheim, Germany). The $\mathrm{CD}^{4+}$ lymphocyte count was estimated by Fluorescence Activated Cell Sorter (FACS) count system (Becton Dickinson, USA).

\subsection{Blood collection and erythrocyte lysate preparation}

Blood samples were collected by venous puncture in heparinized tubes and the plasma was separated by centrifugation at $1000 \mathrm{~g}$ for $15 \mathrm{~min}$. After centrifugation, the buffy coat was removed and the packed cells were washed three times with physiological saline. A known volume of the erythrocytes was lysed with hypotonic phosphate buffer ( $\mathrm{pH}$ 7.4). The hemolysate was separated by centrifugation at $2500 \times \mathrm{g}$ for $15 \mathrm{~min}$ at $2{ }^{\circ} \mathrm{C}$.

\subsection{Estimation of lipid peroxidation}

Lipid peroxides were estimated by measurement of thiobarbituric acid reactive substances (TBARS) in plasma by the method of Yagi [10] and in erythrocytes by the method of Donnan [11]. The pink chromogen produced by the reaction of thiobarbituric acid with malondialdehyde, a secondary product of lipid peroxidation was estimated. Results were expressed as $\mathrm{nmol} / \mathrm{ml}$ for plasma and $\mathrm{pmol} / \mathrm{mg} \mathrm{Hb}$ for erythrocytes. 


\subsection{Estimation of ceruloplasmin}

Ceruloplasmin was determined using its copper oxidase activity by method of Ravin [12]. In this method, action of ceruloplasmin on p-phenylenediamine is used to measure the amount of ceruloplasmin present in the serum. Dark lavender color was read at $530 \mathrm{~nm}$ using control tube as blank. Concentration of ceruloplasmin in $\mathrm{mg} / \mathrm{dl}$ is absorbance $\mathrm{X}$ 87.5.

\subsection{Assay of enzymatic antioxidants}

Superoxide dismutase (SOD) was assayed utilizing the technique of Kakkar [13] based on inhibition of the formation of nicotinamide adenine dinucleotide, phenazine methosulfate and amino blue tetrazolium formazan. A single unit of enzyme was expressed as $50 \%$ inhibition of NBT (Nitroblue tetrazolium) reduction/min/mg $\mathrm{Hb}$. catalase (CAT) was assayed colorimetrically at $620 \mathrm{~nm}$ and expressed as $\mu \mathrm{mol}$ of $\mathrm{H}_{2} \mathrm{O}_{2}$ consumed $/ \mathrm{min} / \mathrm{mg} \mathrm{Hb}$ as described by Sinha [14]. The reaction mixture $(1.5 \mathrm{ml})$ contained $1.0 \mathrm{ml}$ of $0.01 \mathrm{M} \mathrm{pH}$ 7.0-phosphate buffer, $0.1 \mathrm{ml}$ of hemolysate and $0.4 \mathrm{ml}$ of $2 \mathrm{M} \mathrm{H}_{2} \mathrm{O}_{2}$. The reaction was stopped by the addition of $2.0 \mathrm{ml}$ of dichromate-acetic acid reagent (5\% potassium dichromate and glacial acetic acid were mixed in 1:3 ratio). Reduced glutathione (GSH) content was determined by the method of Ellman [15]. $1.0 \mathrm{ml}$ of plasma was treated with $0.5 \mathrm{ml}$ of Ellmans reagent (19.8 mg of 5,5'-dithiobisnitro benzoic acid (DTNB) in $100 \mathrm{ml}$ of $0.1 \%$ sodium nitrate) and $3.0 \mathrm{ml}$ of phosphate buffer $(0.2 \mathrm{M}, \mathrm{pH} 8.0)$. The absorbance was read at $412 \mathrm{~nm}$. Erythrocyte GSH content was determined with dithionitrobenzoic acid using the method described by Beutler and Kelley [16]. GSH content was expressed as $\mathrm{mg} / \mathrm{dl}$.

Glutathione peroxidase (GPx) activity was measured by the method described by Rotruck et al. [17] with modifications. Briefly, reaction mixture contained $0.2 \mathrm{~mL}$ of $0.4 \mathrm{M}$ Tris$\mathrm{HCl}$ buffer $\mathrm{pH} 7.0,0.1 \mathrm{~mL}$ of $10 \mathrm{mM}$ sodium azide, $0.2 \mathrm{~mL}$ of hemolysate, $0.2 \mathrm{ml}$ glutathione and, $0.1 \mathrm{~mL}$ of $0.2 \mathrm{mM} \mathrm{H}_{2} \mathrm{O}_{2}$. The contents were incubated at $37^{\circ} \mathrm{C}$ for 10 min. The reaction was arrested by $0.4 \mathrm{~mL}$ of $10 \% \mathrm{TCA}$, and centrifuged. The supernatant was assayed for glutathione content by using Ellmans reagent (19.8 mg of 5,5'dithiobisnitro benzoic acid (DTNB) in $100 \mathrm{~mL}$ of $0.1 \%$ sodium nitrate). GPx activity was expressed as $\mu \mathrm{moL}$ of $\mathrm{GSH}$ consumed $\mathrm{min} / \mathrm{g} / \mathrm{Hb}$. Glutathione reductase (GR) activity was assayed using oxidized glutathione as a substrate according to the method described by Carlberg and Mannervic [18]. The method was based on the absorbance change at $340 \mathrm{~nm}$ due to oxidation/reduction of NADPH/NADP ${ }^{+}$. GR activity was expressed as $\mu$ mol of NADPH oxidized/h/ml.

Glutathione $S$-transferase (GST) activity was determined spectrophotometrically by the method of Habig et al. [19]. The reaction mixture $(3 \mathrm{ml})$ contained $1.0 \mathrm{ml}$ of $0.3 \mathrm{mM}$ phosphate buffer ( $\mathrm{pH}$ 6.5), $0.1 \mathrm{ml}$ of $30 \mathrm{mM} \mathrm{1-chloro-2,} \mathrm{4-dinitrobenzene} \mathrm{(CDNB)} \mathrm{and}$ $1.7 \mathrm{ml}$ of double distilled water. After preincubating the reaction mixture at $37^{\circ} \mathrm{C}$ for 5 min, the reaction was started by the addition of $0.1 \mathrm{ml}$ of hemolysate and $0.1 \mathrm{ml}$ of 
glutathione as substrate. The absorbance was followed for $5 \mathrm{~min}$ at $340 \mathrm{~nm}$. GST activity was expressed as $\mu \mathrm{mol}$ of CDNB-GSH conjugate formed $/ \mathrm{min} / \mathrm{mg} \mathrm{Hb}$.

\subsection{Estimation of non-enzymatic antioxidants and Micronutrients}

Plasma vitamin A was estimated by the method of Bradly and Hombeck [20]. Proteins were precipitated with ethanol and the carotenes were extracted into light petroleum. The intensity of the yellow color due to carotene was read directly at $450 \mathrm{~nm}$ using a violet filter. Vitamin E was measured by the method of Baker et al. [21] on the basis of the reduction of ferric ions to ferrous ions by vitamin $\mathrm{E}$ and the formation of a red colored complex with 2.2'-dipyridyl at $520 \mathrm{~nm}$. Vitamin $\mathrm{C}$ was estimated by the method of Roe and Kuether [22]. This involves oxidation of ascorbic acid by copper followed by treatment with 2,4-dinitrophenylhydrazine that undergoes rearrangement to form a product with absorption maximum at $520 \mathrm{~nm}$. Plasma selenium was measured by atomicabsorption spectrophotometry method by Neve et al. [23]. Zinc was estimated by the method of Arnaud et al. [24].

\subsection{Statistical analysis}

All data were expressed as mean $\pm \mathrm{SD}$. The statistical significance was evaluated by Student's $t$ test and the Mann-Whitney U-test was used. Statistical analyses were performed with Statistical Package for Social Sciences software (SPSS Cary, NC, USA) version 10.0. A $p$ value of less than $<0.05$ was considered statistically significant.

\section{Results}

Information about the investigated characteristics is shown in Table 1. The mean age limit was $49 \pm 13.4$ in AIDS patients, $44 \pm 10.2$ in HIV infected patients and $42 \pm 9.3$ in control subjects. The decrease body mass index in AIDS patients $\left(22.5 \pm 6.9 \mathrm{~kg} / \mathrm{m}^{2}\right)$ compared with HIV infected patients $\left(30.8 \pm 7.1 \mathrm{~kg} / \mathrm{m}^{2}\right)$ and control subjects $\left(32.7 \pm 6.7 \mathrm{~kg} / \mathrm{m}^{2}\right)$ were statistically significant. On the other hand the drastically decrease body mass index in AIDS patients compare with HIV infection was highly significant. The increased number of hypertension, smokers and alcoholics were observed in AIDS patients compared with HIV infection and control subjects. All the risk factors significantly changed in AIDS patients compared with HIV infected subjects Diabetic participants were defined as those with a fasting blood glucose concentration $\geq 120-\mathrm{mg} / \mathrm{dl}$.

Table 2 shows the levels of $\mathrm{CD}^{4+}$ cell count, total RBC count, WBC count, platelet count, hemoglobin, hematocrit and ESR in control, HIV infected and AIDS patients. The levels of $\mathrm{CD}^{4+}$ cell count, total $\mathrm{RBC}$ count, platelet, hemoglobin and hematocrit were significantly decreased in AIDS patients when compared with HIV infected patients and control subjects. On the other hand, the level of total WBC count and ESR were significantly increased in HIV infected and AIDS patients. The above-mentioned 
hematological parameters were found to be more significantly altered in AIDS patients compared with HIV infected subjects.

Table 1. Demographic characteristics of different study group.

\begin{tabular}{lccc}
\hline Parameter & Control subjects & HIV infection & AIDS patients \\
\hline Total number of subjects $(\mathrm{n})$ & 50 & 50 & 50 \\
Sex (male) & $100 \%$ & $100 \%$ & $100 \%$ \\
Mean age (mean $\pm \mathrm{SD}$; years) & $42 \pm 9.3$ & $44 \pm 10.2^{\mathrm{NS}}$ & $49 \pm 13.4^{* *}$ \\
Body mass index $\left(\mathrm{kg} / \mathrm{m}^{2}\right)$ & $32.7 \pm 6.7$ & $30.8 \pm 7.1^{\mathrm{NS}}$ & $22.5 \pm 6.9^{* \ddagger}$ \\
Risk factors & $8 \%$ & $70.5 \%$ & $87.5 \%$ \\
Hypertension & - & $28 \%$ & $27 \%$ \\
Diabetes mellitus & $10 \%$ & $53 \%$ & $85 \%$ \\
Smokers & $11 \%$ & $60 \%$ & $80 \%$ \\
Alcoholics & & & \\
\hline
\end{tabular}

Values are given as mean \pm S.D from fifty subjects in each group.

*AIDS patients compared with control subjects; ${ }^{\ddagger}$ AIDS patients compare with HIV infection; NS - Non significant; $\mathrm{p}<0.05$ considered statistically significant.

Table 2. Blood picture of the subjects investigated.

\begin{tabular}{lccc}
\hline Parameter & Control subjects & HIV infection & AIDS patients \\
\hline RBC count $\left(10^{6} / \mu \mathrm{l}\right)$ & $5.5 \pm 0.65$ & $5.1 \pm 0.72^{*}$ & $3.1 \pm 0.61^{* \ddagger}$ \\
WBC count $\left(10^{6} / \mu \mathrm{l}\right)$ & $7.8 \pm 2.0$ & $9.7 \pm 3.2^{*}$ & $11.3 \pm 2.6^{* \ddagger}$ \\
$\mathrm{CD}^{4+}$ cell count $(\mathrm{Cells} / \mu \mathrm{l})$ & $750 \pm 95$ & $375 \pm 72^{*}$ & $150 \pm 65^{* *}$ \\
Hemoglobin $(\mathrm{g} / \mathrm{dl})$ & $14.7 \pm 1.6$ & $12.6 \pm 1.8^{*}$ & $9.6 \pm 2.0^{*}$ \\
Hematocrit $(\%)$ & $44.1 \pm 4.2$ & $38.0 \pm 4.0^{*}$ & $27.1 \pm 6.1^{*}$ \\
Platelet count $\left(\mathrm{Cells} / 10^{3} \mu \mathrm{l}\right)$ & $250 \pm 60$ & $95 \pm 36^{*}$ & $39 \pm 52^{*}$ \\
ESR $(\mathrm{mm} / \mathrm{hr})$ & $7 \pm 4.5$ & $75 \pm 26^{*}$ & $145 \pm 35^{*}$ \\
\hline
\end{tabular}

Values are given as mean \pm S.D from fifty subjects in each group.

*AIDS patients compared with control subjects; *HIV infection compare with control subjects;

AIDS patients compare with HIV infection; $p<0.05$ considered statistically significant.

Table 3 shows the levels of erythrocyte TBARS and enzymatic antioxidant status in SOD, CAT, GSH, GPx, GR and GST in control subjects, HIV infection and AIDS patients. Lipid peroxidation indicated by erythrocyte TBARS level was significantly higher in AIDS patients when compared to HIV infected patients and control subjects. The decrease in the levels of erythrocyte enzymatic antioxidant status in SOD, CAT, GSH, GPx, GR and GST in AIDS patients when compared to HIV infected patients and control subjects were statistically significant. On the other hand the level of lipid peroxidation and erythrocyte enzymatic antioxidant profile were found to be more significantly altered in AIDS patients compared with HIV infected subjects. 
Table 3. The level of erythrocyte TBARS, SOD, CAT, GSH, GPx, GR and GST in control subjects, HIV infection and AIDS patients.

\begin{tabular}{lccc}
\hline Parameter & $\begin{array}{c}\text { Control } \\
\text { subjects }\end{array}$ & HIV infection & AIDS patients \\
\hline TBARS $(\mathrm{pmol} / \mathrm{mg} \mathrm{Hb})$ & $3.76 \pm 0.71$ & $8.52 \pm 2.30^{*}$ & $12.87 \pm 3.52^{* *}$ \\
SOD $\left(\mathrm{U}^{\mathrm{A}}\right)$ & $4.91 \pm 0.66$ & $2.74 \pm 0.17^{*}$ & $1.24 \pm 0.15^{*}$ \\
$\mathrm{CAT}\left(\mathrm{U}^{\mathrm{B}}\right)$ & $80.5 \pm 7.60$ & $52.81 \pm 8.70^{*}$ & $32.3 \pm 7.90^{*}$ \\
$\mathrm{GSH}(\mathrm{mg} / \mathrm{dl})$ & $53.42 \pm 8.52$ & $40.43 \pm 7.75^{*}$ & $29.23 \pm 7.3^{* *}$ \\
GPx $\left(\mathrm{U}^{\mathrm{C}}\right)$ & $12.15 \pm 2.69$ & $7.93 \pm 0.85^{*}$ & $3.53 \pm 0.85^{*}$ \\
GR $\left(\mathrm{U}^{\mathrm{D}}\right)$ & $32.50 \pm 2.73$ & $20.53 \pm 4.50^{*}$ & $14.47 \pm 3.72^{*}$ \\
GST $\left(\mathrm{U}^{\mathrm{E}}\right)$ & $3.90 \pm 0.30$ & $2.42 \pm 0.55^{*}$ & $1.02 \pm 0.45^{*}$ \\
\hline
\end{tabular}

Values are given as mean \pm S.D from fifty subjects in each group.

*AIDS patients compared with control subjects; *HIV infection compare with control subjects;

${ }^{\ddagger}$ AIDS patients compare with HIV infection; $p<0.05$ considered statistically significant.

A-One unit of activity was taken as the enzyme reaction, which gave $50 \%$ inhibition of NBT reduction $/ \mathrm{min} / \mathrm{mg} \mathrm{Hb}$.

$\mathrm{B}-\mu \mathrm{mol}$ of $\mathrm{H}_{2} \mathrm{O}_{2}$ consumed $/ \mathrm{min} / \mathrm{mg} \mathrm{Hb} ; \mathrm{C}-\mu \mathrm{mol}$ of $\mathrm{GSH}$ consumed $/ \mathrm{min} / \mathrm{mg} \mathrm{Hb}$.

D- $\mu \mathrm{mol}$ of NADPH oxidized $/ \mathrm{h} / \mathrm{ml}$; E - $\mu \mathrm{mol}$ of CDNB-GSH conjugate formed $/ \mathrm{min} / \mathrm{mg} \mathrm{Hb}$.

Table 4 shows the levels of plasma TBARS, ceruloplasmin, plasma vitamins A, vitamin $\mathrm{C}$, vitamin E, GSH, serum uric acid, serum albumin and micronutrients (selenium and zinc) in control subjects, HIV infection and AIDS patients. Lipid peroxidation indicated by plasma TBARS level was significantly higher in AIDS patients when compared to HIV infected patients and control subjects. The decrease in the levels of plasma vitamins A, C, $\mathrm{E}$ and GSH in AIDS patients when compared to HIV infected patients and control subjects were statistically significant. On the other hand the level of plasma lipid peroxidation and

Table 4. Levels of plasma TBARS, ceruloplasmin, plasma antioxidants vitamin A, vitamin $\mathrm{C}$, vitamin $\mathrm{E}, \mathrm{GSH}$, uric acid, albumin and micronutrients (selenium and zinc) in control subjects, HIV infection and AIDS patients.

\begin{tabular}{lccc}
\hline Parameter & Control subjects & HIV infection & AIDS patients \\
\hline TBARS $(\mathrm{nmol} / \mathrm{ml})$ & $2.76 \pm 0.35$ & $6.51 \pm 0.90^{*}$ & $9.14 \pm 1.84^{*}$ \\
Ceruloplasmin $(\mathrm{mg} / \mathrm{dl})$ & $27.69 \pm 8.04$ & $35.11 \pm 7.81^{*}$ & $68.15 \pm 10.15^{*}$ \\
GSH $(\mathrm{mg} / \mathrm{dl})$ & $38.34 \pm 1.83$ & $30.73 \pm 2.75^{*}$ & $19.26 \pm 4.15^{*}$ \\
Vitamin A $(\mathrm{mg} / \mathrm{dl})$ & $0.82 \pm 0.090$ & $0.51 \pm 0.076^{*}$ & $0.18 \pm 0.056^{*}$ \\
Vitamin C $(\mathrm{mg} / \mathrm{dl})$ & $1.10 \pm 0.26$ & $0.65 \pm 0.21^{*}$ & $0.23 \pm 0.16^{*}$ \\
Vitamin E $(\mathrm{mg} / \mathrm{dl})$ & $1.32 \pm 0.28$ & $0.98 \pm 0.19^{*}$ & $0.36 \pm 0.23^{*}$ \\
Uric acid $(\mathrm{mg} / \mathrm{dl})$ & $4.23 \pm 1.76$ & $6.54 \pm 2.42^{*}$ & $8.71 \pm 3.14^{*}$ \\
Albumin $(\mathrm{mg} / \mathrm{dl})$ & $4.52 \pm 1.28$ & $3.89 \pm 0.84^{*}$ & $3.11 \pm 0.49^{*}$ \\
Selenium $(\mu \mathrm{M} / \mathrm{l})$ & $0.99 \pm 0.18$ & $0.83 \pm 0.15^{*}$ & $0.51 \pm 0.23^{*}$ \\
Zinc $(\mu \mathrm{M} / \mathrm{l})$ & $15.72 \pm 4.2$ & $11.68 \pm 3.15^{*}$ & $8.37 \pm 3.89^{* *}$ \\
\hline
\end{tabular}

Values are given as mean \pm S.D from fifty subjects in each group.

*AIDS patients compared with control subjects; ${ }^{*} \mathrm{HIV}$ infection compare with control subjects;

AIDS patients compare with HIV infection; $p<0.05$ considered statistically significant. 
vitamins levels were found to be more significantly altered in AIDS patients compared with HIV infected subjects. Serum uric acid, albumin and micronutrients selenium and zinc levels are significantly decreased in AIDS patients when compared to HIV infected patients and control subjects.

\section{Discussion}

Human monocyte-derived macrophages are involved in a variety of pathological events in HIV infection the hallmark of which is immunodeficiency with progressive $\mathrm{CD}^{+} \mathrm{T}$ lymphocyte depletion. HIV infections cause a chronic inflammation as shown by high plasma levels of inflammatory cytokines and production of ROS in seropositive individuals. Hematological abnormalities are among the most common complications of infection with HIV [3, 25].

This increase in oxidative stress documented in our HIV/AIDS patients may have some clinical significance because there is experimental evidence implicating oxidative stress in the stimulation of HIV replication. In vitro experiments have shown that ROS such as hydrogen peroxide can specifically activate the nuclear factor kB to induce the expression and replication of HIV-1 in a human T cell line, and addition of antioxidant vitamins blocked activation of nuclear factor $\mathrm{kB}$ and inhibited HIV replication [6]. In HIV infection, ROS species may enhance viral replication by activating nuclear transcription factors, which ultimately could lead to viral gene expression. The deficiency of total antioxidant status might markedly increase oxidative stress, possibly adversely affecting the immune system $[3,10,11]$.

An increase in plasma concentration of the by-product of lipid peroxidation (TBARS) was also detected in HIV+ patients. This increase is consistent with the finding of other studies that showed oxidative stress in $\mathrm{HIV}+$ patients as evidenced by TBARS concentration [26]. The similar trends between TBARS suggest the role of lipid peroxidation in the loss of redox cellular status in HIV patients. The observed increase of oxidative stress processes in these patients resulting from cytotoxic products may modify proteins and DNA by addition reactions. Other experiments suggesting that lipid peroxidation is much more important in the asymptomatic stage rather than in AIDS. Ceruloplasmin has also been demonstrated to have week $\mathrm{O}_{2}^{-}$scavenging activity. However, when lipid peroxidation is promoted by copper ions, ceruloplasmin displays a potent antioxidant activity. It is therefore tempting to speculate that the marked increase in plasma ceruloplasmin levels in HIV/AIDS patients is a physiological adaptation to the need for antioxidant protection in the event of a breakdown in other antioxidant defense mechanisms [3, 11].

Peroxides serve as a source for hydroxyl or peroxyl reactive radicals that can interact with cellular components inducing cell damage potentially leading to cell death. The increase of $\mathrm{TH}$ observed in $\mathrm{HIV}^{+}$patients emphasizes the higher oxidative stress, which occurs during HIV infection. It should also be noted that peroxides and aldehydes generated are not only passive markers of oxidative stress, but also cytotoxic products 
[27]. It is thus important to evaluate the role to these oxidative products in lymphocyte death. The pathology of ROS is related to oxidation of nucleic acids and chromosome breaks. Limited chromosomal damage can be repaired, however, extensive DNA damage promotes apoptosis, which is recognized as a major form of cell death of $\mathrm{CD}^{+}$ lymphocytes in HIV infection [3].

The production of free radicals could thus mediate (or be concomitant with) the expression of genes activated by TNF. Oxygen radicals will participate in the activation of a nuclear transcription factor called NFK-B, which is very important for the life of lymphocytes. SOD is the key enzyme in cell protection from the apoptosis induced by TNF. This action of the viral protein may thus contribute to lymphocyte death in a patient who is already antioxidant deficient, under the action of free radicals generated by TNF $[3,28]$.

This study suggests that enhanced oxidative stress and disturbed glutathione metabolism. These effects appear to be related to persistent tumor necrosis factor- $\alpha$ (TNF$\alpha$ ) activation in HIV-infected patients. HIV-infected individuals have been shown to decrease antioxidant concentrations, disruption in glutathione metabolism, and enhanced spontaneous generation of $\operatorname{ROS}[3,11,29]$. Furthermore, a significant decrease in GR levels was documented. To be cognizant, lower GR levels and oxidative stress in general are known to up regulate inflammatory cytokine activities. GPx plays an important role in the metabolism of ROS as a defense mechanism against oxidative damage by catalyzing the reduction of a variety of hydroperoxides via glutathione as the reducing substrate. In addition to its role as a substrate in the GSH redox cycle, glutathione also acts as a direct endogenous scavenger of hydroxyl radicals, and is involved in the detoxification and metabolism of a number of chemicals and drugs in the liver. Antioxidant enzyme levels are sensitive to oxidative stress; alterations were observed in the present study, which prove the cell damage and weakened antioxidant defense in HIV-infected individuals [30, 31].

In addition to an excessive production of ROS, which may be explained by polymorphonuclear leukocyte activation during infectious conditions or by a prooxidant effect of tumor necrosis factor a produced by activated macrophages, a weakened antioxidant defense system may play a role. To our knowledge, our study is the first to document significantly higher oxidative stress and lower concentrations of major plasma antioxidants (ascorbic acid, $\alpha$-tocopherol, $\beta$-carotene, and selenium) in the same HIVpositive subjects than in seronegative control subjects [32-34]. In fact, in HIV-positive patients selenium concentrations and glutathione concentrations were found to be low. This antioxidant deficiency in HIV/AIDS populations is probably due to increased utilization of antioxidant micronutrients because of increased oxidative stress rather than to inadequate dietary intake. This study documents alterations in the levels of antioxidant status, albumin and uric acid levels were significantly decreased in AIDS patients when compared with HIV infected patients and control subjects. Studies from the developed world have documented biochemical changes that could be a result of greater utilization 
of antioxidant micronutrients subsequent to increased oxidative stress rather than inadequate dietary intake or malabsorption [35].

\section{Conclusion}

This study showed that a lipid peroxidation concentration was significantly higher in HIVinfection and AIDS patients than in seronegative control subjects. It also highlights the occurrence of lipid peroxidation and possible breakdown of antioxidant status in HIV/AIDS patients, which may subsequently increase the possibility of poor immunity. These results along with the findings reported in the literature suggest that a weakened antioxidant defense system may play a significant role in the increased oxidative stress found in the HIV/AIDS patients, whether due to increased consumption or reduced intakes of antioxidant micronutrients. The indicators evaluated could contribute to an integral overview in HIV infection. Further studies may be justified to evaluate the role of ROS as apoptosis mediators and as indices of treatment efficacy. However, it remains to be determined whether antioxidant supplementation will have any effect, not only on oxidative stress but also on viral replication and disease progression.

\section{References}

1. S. T. Rasool, H. Tang, J. Wu, W. Li, M. M. Mukhtar, J. Zhang, Y. Mu, H. X. Xing, J. Wu, and Y. Zhu, Immuno. Lett. 117, 161 (2008). doi:10.1016/j.imlet.2008.01.007

2. L. Gil, G. Martynez, I. Gonzalez, A. Tarinas, A. Alvarez, A. Giuliani, R. Molina, R. Tapanes, J. Perez, and O. S. Leon, Pharmacological Research 47, 217 (2003). doi:10.1016/S1043-6618(02)00320-1

3. N. Israel, and M. A. Gougerot-Pocidalo, CMLS. 53, 864 (1997). doi:10.1007/s000180050106

4. J. Caamano, and C. A. Hunter, Clin. Microbiol. Rev. 15 (3), 414 (2002). doi:10.1128/CMR.15.3.414-429.2002

5. E. M. Sloand, N. S. Young, P. Kumar, F. F. Weichold, T. Sato, and J. P. Maciejewski, Blood 89, 1357 (1997).

6. S. Aquaro, F. Scopelliti, M. Pollicita, and C. F. Perno, Future HIV Therapy 2, 327 (2008).

7. M. Sundaram, S. Saghayam, B. Priya, K.K. Venkatesh, P. Balakrishnan, E.M. Shankar, K.G. Murugavel, S. Solomon, and N. Kumarasamy, IJID. 12, e61-e66 (2008).

8. National AIDS Control Organization (NACO), Ministry of Health and Family Welfare. HIV/AIDS Specialist training and reference module, Government of India, New Delhi 5-8 (2003).

9. Center for Disease Control (CDC). Morb. Mortal. Wiley Rep. 14, 1 (1993).

10. K. Yagi, Chem. Phys. Lipids 45, 337 (1978). doi:10.1016/0009-3084(87)90071-5

11. S. K. Donnan, J. Biol. Chem. 182, 415 (1950).

12. H. A. Ravin, J. Lab. Clin. Med. 58 (1), 161 (1961).

13. P. S. Kakkar, B. Das, and P. N. Viswanathan, Indian J. Biochem. Biophys. 21, 130 (1984).

14. K. A. Sinha, Anal. Biochem. 47, 389 (1972). doi:10.1016/0003-2697(72)90132-7

15. G. L. Ellman, Arch. Biochem. Biophys. 82, 70 (1959). doi:10.1016/0003-9861(59)90090-6

16. E. Beutler and B. M. Kelley, Experientia 19, 96 (1963). doi:10.1007/BF02148042

17. J. T. Rotruck, A. L. Pope, H. E. Ganther, A. B. Swanson, D. G. Hafeman, and W. G. Hoekstra, Science 179, 588 (1973). doi:10.1126/science.179.4073.588

18. I. Carlberg and B. Mannervik, Methods in enzymalogy (Accademic Press, New York, 484, 1985).

19. W. H. Habig, M. J. Pabst, and W. B. Jakoby, J. Biol. Chem. 249, 7130 (1974). 
20. D.W. Bradley and C. L. Hombeck, 1973. Biochemical Medicine 7, 78 (1973). doi:10.1016/0006-2944(73)90101-4

21. H. Baker, O. Frank, B. De Angelis, and S. Feingold, Nutrition Report International 21, 531 (1980).

22. H. J. Roe and C. A. Kuether, Journal of Biological Chemistry 147, 399 (1943).

23. J. Neve, S. Charmart, and L. Mole, Trace element analytical chemistry in medicine and biology (Walter de Gruyter Press, Berlin, 1987) pp. 349-359.

24. J. Arnaud, J. Bellanger, F. Bienvenu, P. Chappuis, and A. Favier, Ann. Biol. Clin. 44, 77 (1986).

25. I. M. Adetifa, E. O. Temiye, A. O. Akinsulie, V. C. Ezeaka, and E. O. Iroha, Annals of Tropical Paediatrics 26 (2), 121 (2006). doi:10.1179/146532806X107467

26. L. L. Zwart, J. H. N. Meerman, J. N. M. Commandeur, and N. P.E. Vermeulen, Free Radic. Biol. Med. 26 (1/2), 202 (1999).

27. H. Groux, D. Monte, J. M. Bourrez, A. Capron, and J. C. Ameisen, C. R. Acad. Sci. 312, 599 (1991).

28. A. Cariappa, Liou, H. C., Horwitz, and B. H. Pillai, S, J. Exp. Med. 192, 1175 (2000).

29. M. C. Delmas-Beauvieux, E. Peuchant, A. Couchouron, J. Constans, C. Sergeant, and M. Simonoff, Am. J. Clin. Nutr. 64, 101 (1996).

30. G. Wu, Y. Z. Fang, S. Yang, J. R. Lupton, and N. D. Turner, J. Nutr. 134 (3), 489 (2004).

31. W. W. Fawzi, G. I. Msamanga, and D. Spiegelman, N. Engl. J. Med. 351, 23 (2004). doi:10.1056/NEJMoa040541

32. H. Sakagami, K.Asano, K. Satoh, K. Takahashi, M. Kobayashi, N. Koga, H. Takahashi, R. Tachikawa, T. Tashiro, A. Hasegawa, K. Kurihara, T. Ikarashi, T. Kanamoto, S. Terakubo, H. Nakashima, S. Watanabe, and W. Nakamura, In Vivo 21 (3), 499 (2007).

33. R. Kupka, G. I Msamanga, D. Spiegelman, S. Morris, F. Mugusi, D. J. Hunter, and W. W. Fawzi, J. Nutr. 134, 2556 (2004).

34. C. Spada, A. Treitinger, M. Reis, I. Y. Masokawa, J. C. Verdi, M. C. Luiz, M. V. S. Silveira, O. V. Oliveira, C. M. Michelon, S. Avila-Junior, I. D. O. Gil, and S. Ostrowsky, Clin. Chem. Lab. Med. 40, 456 (2002). doi:10.1515/CCLM.2002.078

35. A. L. Webb and E. Villamor, Nutr. Rev. 65 (5), 181 (2007). doi:10.1111/j.1753-4887.2007.tb00298.x 